\title{
Factor analysis on land subsidence in the Nobi Plain, southwest Japan
}

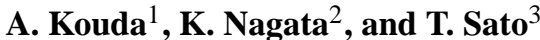 \\ ${ }^{1}$ Teikoku International Corporation, 2-8 Hashimoto-cho, Gifu, Japan \\ ${ }^{2}$ Geospatial Information Authority of Japan, 2-5-1 Sannomaru, Naka-ku, Nagoya, Japan \\ ${ }^{3}$ Dept. of Civil Engineering, Gifu University, 1-1 Yanagido, Gifu, Japan \\ Correspondence to: A. Kouda (kouda@teikoku-eng.co.jp)
}

Published: 12 November 2015

\begin{abstract}
The land subsidence of the Nobi Plain largely ceased with the commencement of pumping regulations beginning in 1975. However, a small amount of land subsidence, less than one centimeter, is still observed at the Delta zone in the southwest part of the Plain. The authors attempted to investigate the cause of the small amount of existing subsidence. The alluvial clay layer deposits are more than $15-20 \mathrm{~m}$ thick and the withdrawal is small. The decrease of the yearly average groundwater level has not been confirmed.

On the other hand, the seasonal change in the groundwater level is clearly observed. This investigation focuses on the seasonal change of groundwater level each year and its relation to the thickness of alluvial clay layer. The Delta zone was divided into several cells and a multiple regression analysis was applied to the seasonal change of the groundwater level and the thickness of alluvial clay layer of the cell. The study concluded that the small amount of land subsidence was caused of drawdown of piezometric head of groundwater every year during the summer.
\end{abstract}

\section{Introduction}

Three large rivers (Fig. 1), the Kiso R. to the east, the Nagara $\mathrm{R}$. in the middle and the Ibi R. in the west, flow it into the Ise Bay which is located at the bottom of Fig. 1.

The area of the plain is almost $1300 \mathrm{~km}^{2}$ and the population reached almost 6 million in 2010 which is a $16 \%$ increases from 2005. Average precipitation has been recorded as $1543 \mathrm{~mm}$ year -1 since 1961 . Groundwater withdrawal was recorded as 1251 million $\mathrm{m}^{3}$ year-1 in 1976 , which breaks down to 743 million $\mathrm{m}^{3}$ for industry, 228 million $\mathrm{m}^{3}$ for drinking and 156 million $\mathrm{m}^{3}$ for agricultural use.

Large amounts of land subsidence have occurred due to excess groundwater use (Fig. 2). Groundwater use has been regulated since 1975. As a result the piezometric heads have gradually increased and the rate of land subsidence has gradually decreased. However, small amounts of land subsidence have continued in the Delta zone of the southwest part since the 1980s (Fig. 3). Groundwater use in the Delta zone is small. However, $15-20 \mathrm{~m}$ of soft alluvial clay occur in this area.
In this paper, we conducted a factor analysis using the potential factors and the induction factor for the Delta zone to elucidate the cause of the small amount of ongoing land subsidence.

\section{Multiple regression analysis of land subsidence}

\subsection{Features of land subsidence}

Since 1989 the land subsidence area shows good agreement with the area of the alluvial clay layer with more than $15 \mathrm{~m}$ thickness (Fig. 4). Piezometric groundwater levels severely drop more than $2 \mathrm{~m}$ in the summer in the northern part of the area, A decrease of piezometric head in the Delta zone and is estimated to be about $0.2-2.0 \mathrm{~m}$ each year during the summer (Fig. 5). Figure 5 indicates that the area of greatest cumulative land subsidence does not necessarily align with that of groundwater level declines each year during the summer. Special attention is placed on the relationship between piezometric head decline and thickness of the alluvial clay layer and cumulative land subsidence amount. 


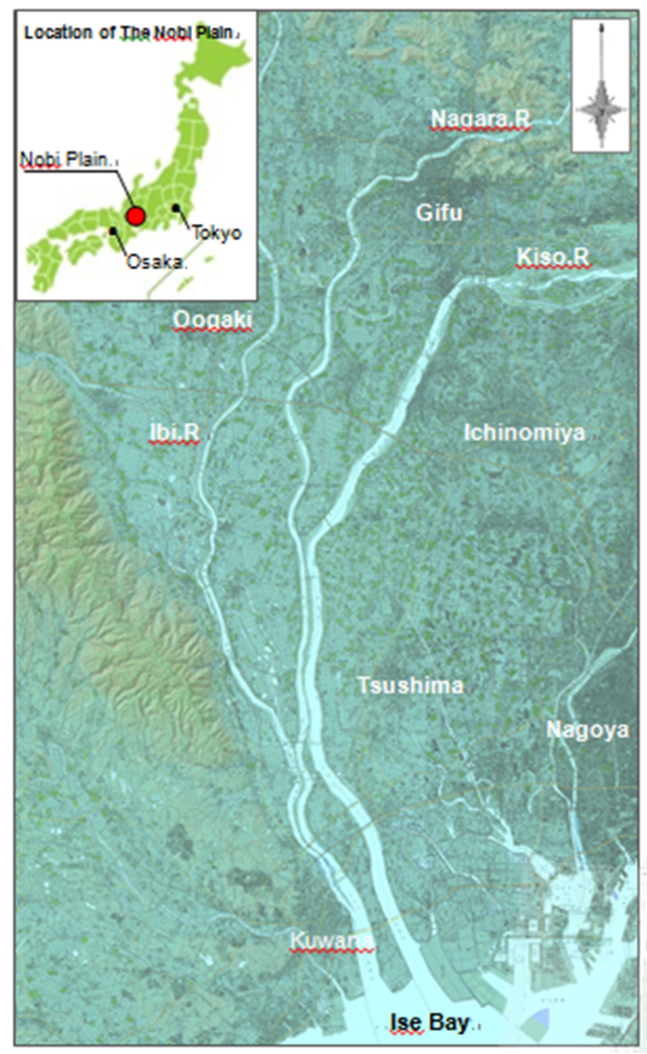

Figure 1. Reserch area and major rivers.

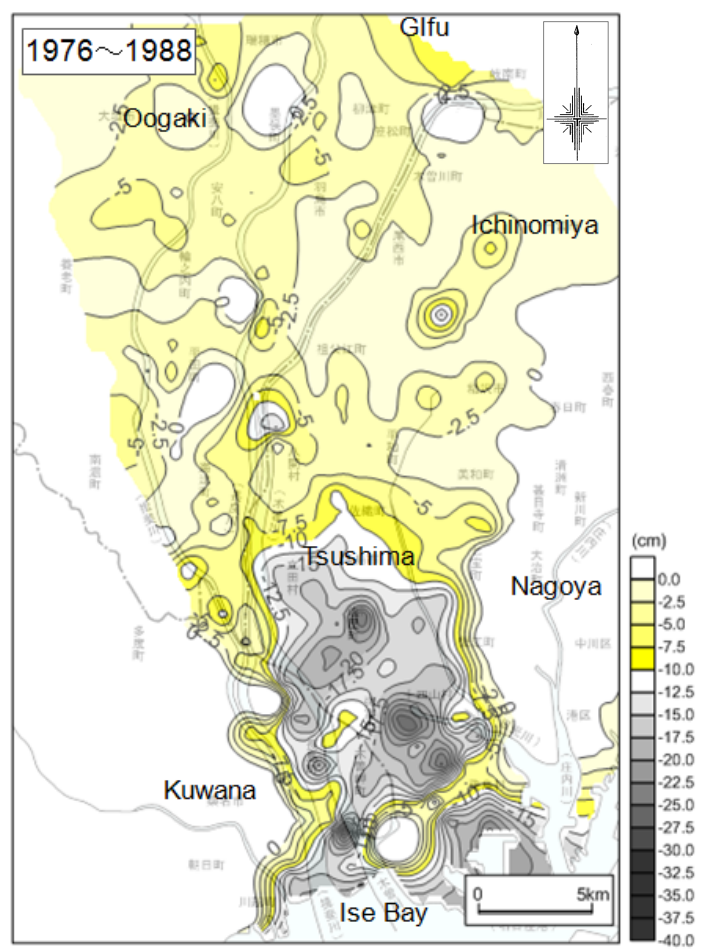

Figure 2. Cumulative land subsidence amount in the Nobi Plain (1976-1988).

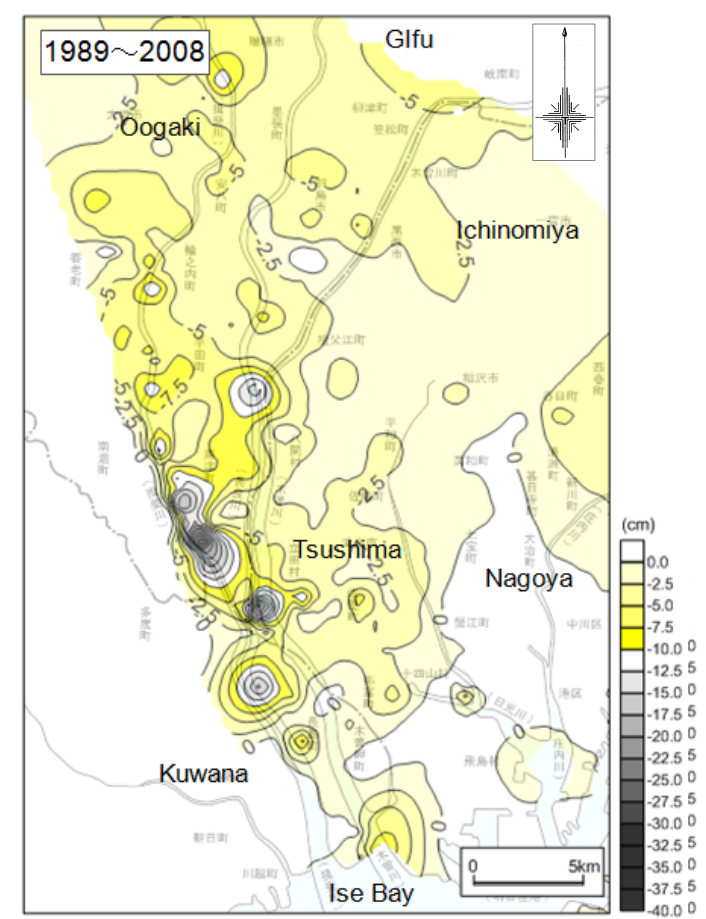

Figure 3. Cumulative land subsidence amount in the Nobi Plain (1989-2008).

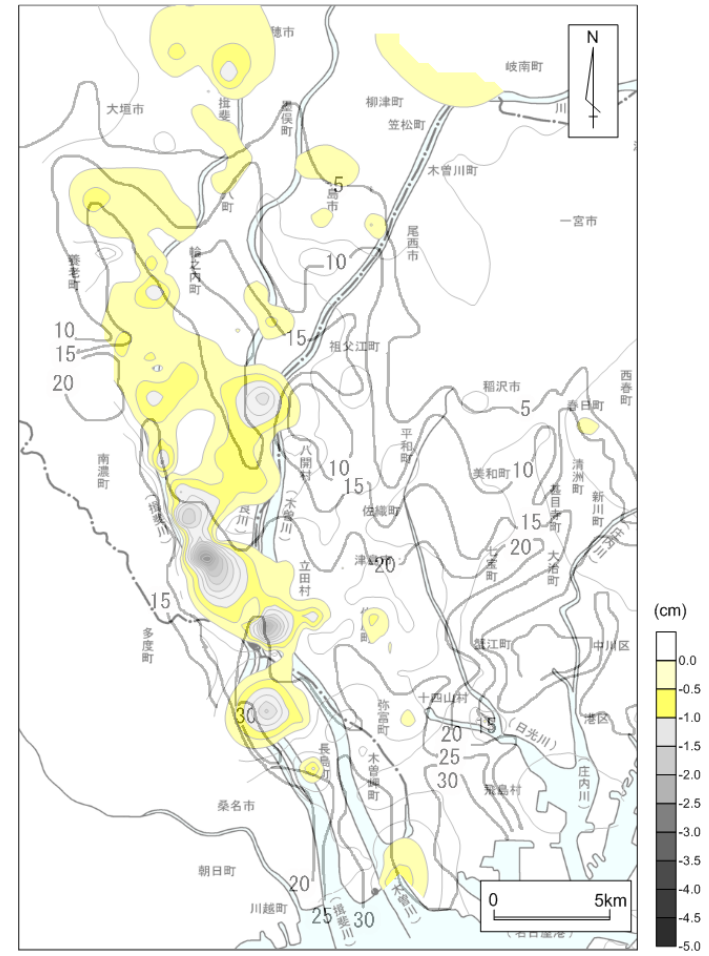

Figure 4. The thickness of alluvial clay layer and land subsidence area $(\mathrm{m})$. 


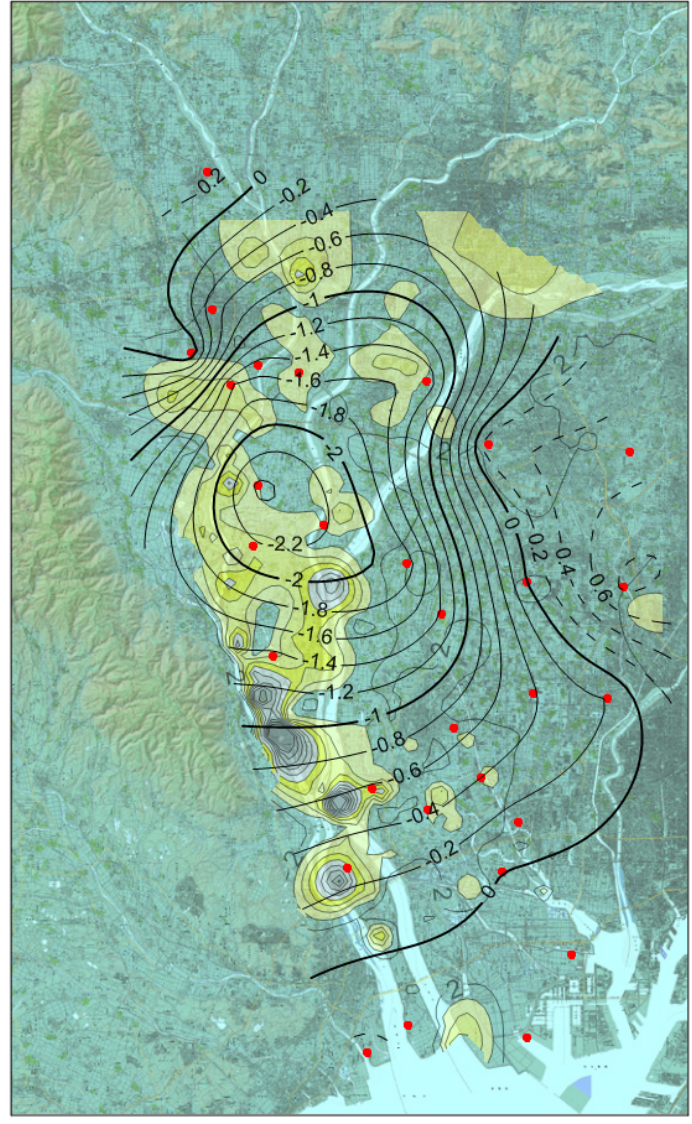

Figure 5. Decrease of piezometric head of groundwater in summer and land subsidence area (2007).

\subsection{Model of the regression analysis}

The research area is divided into 32 cells each with a length of $5.7 \mathrm{~km}$ in the east-west direction and $4.6 \mathrm{~km}$ in the north-south direction (Fig. 6). The measured values at the 307 benchmarks are applied to the calculation of the cumulative land subsidence of the cells. The results during 17 years of analysis, from 1989 to 2006, are shown in Fig. 7. The thickness of the alluvial clay layer is shown in Fig. 8. Seasonal variation of piezometric head of groundwater was calculated from differences in the yearly average groundwater level from 1989 to 2006 from the 28 observation wells. The amount of seasonal variation in each cell, $\Delta P$ is determined from the isolines of the seasonal variation, which is derived from the difference of the yearly average value of the piezometric head of groundwater during the summer (from June to September) and the winter (from October to May). The amount of $\Delta P$ is obtained from the difference between the yearly average value of piezometric head of groundwater in the winter and the yearly average value of piezometric head of groundwater in the summer. Positive values represent the decline in the piezometric head during the summer season (Fig. 9).

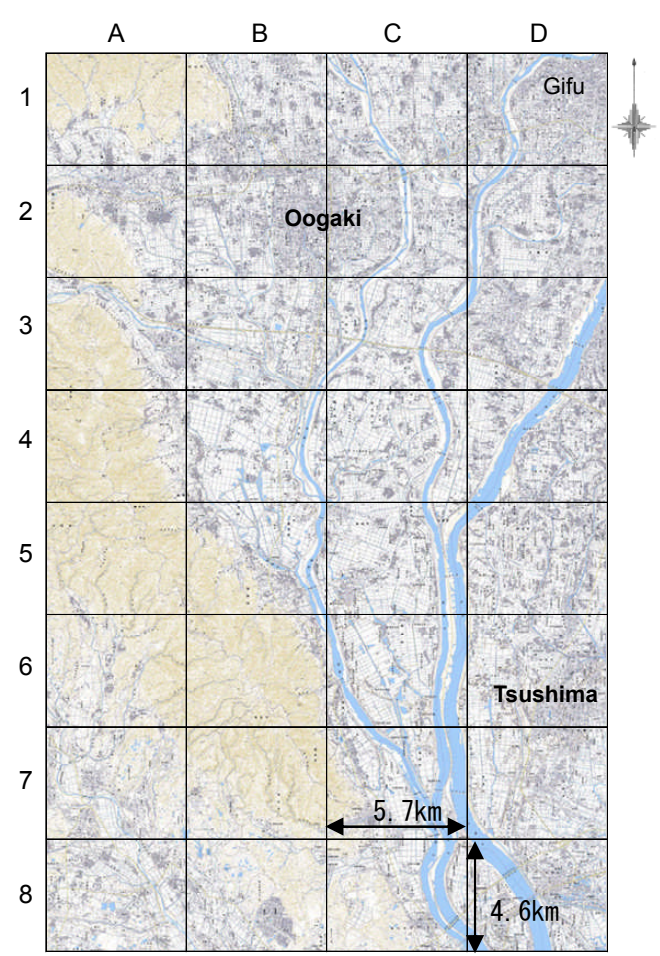

Figure 6. Analysis area.

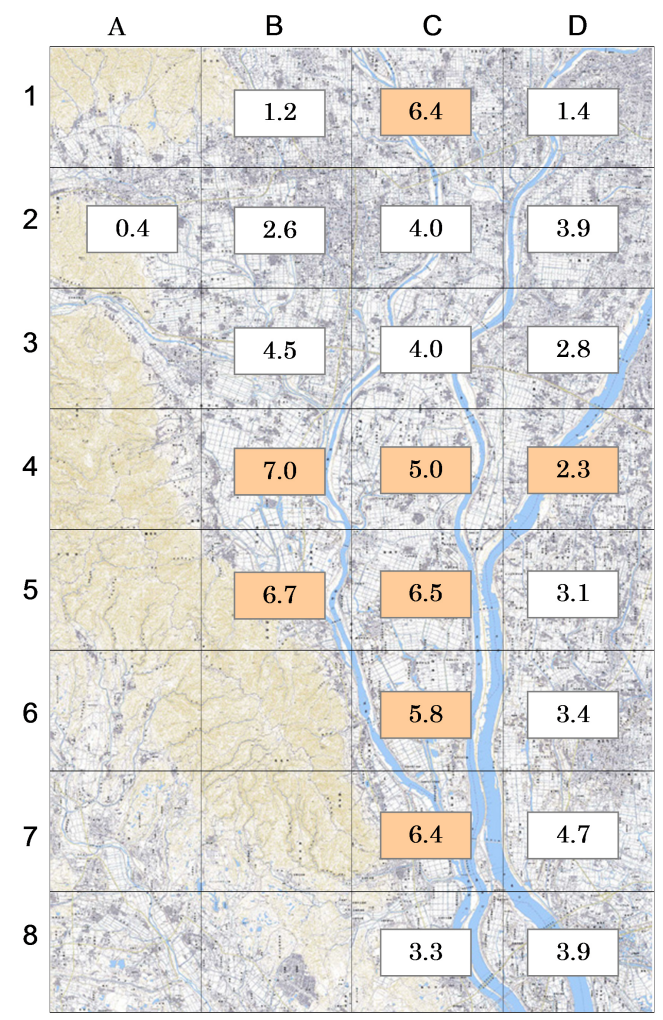

Figure 7. Average Cumulative value of land subsidence (19892006). 


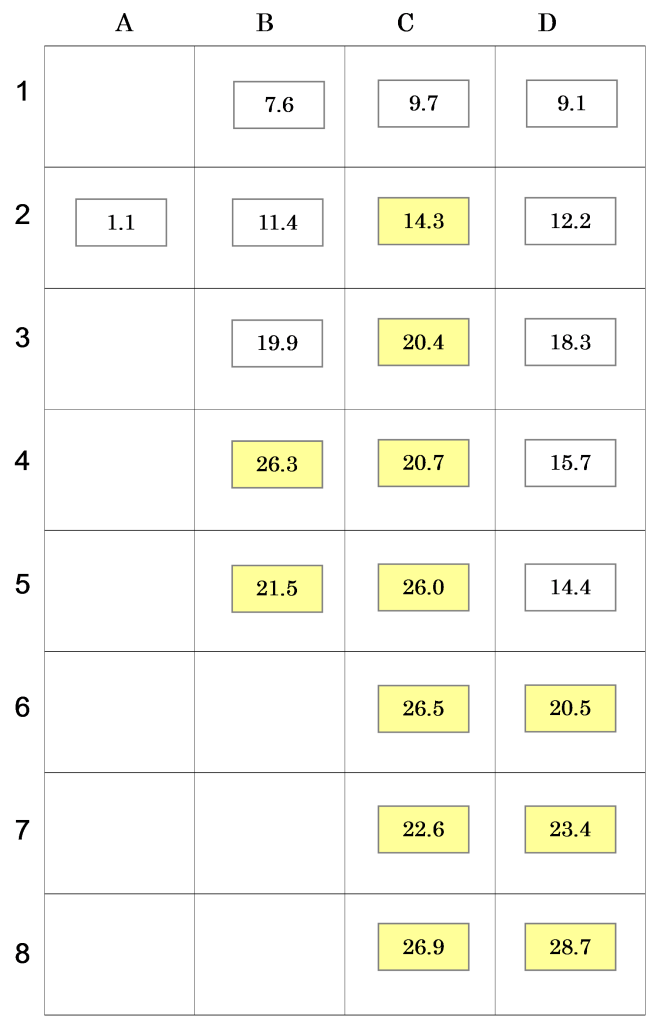

Figure 8. Average thickness of alluvial clay layer.

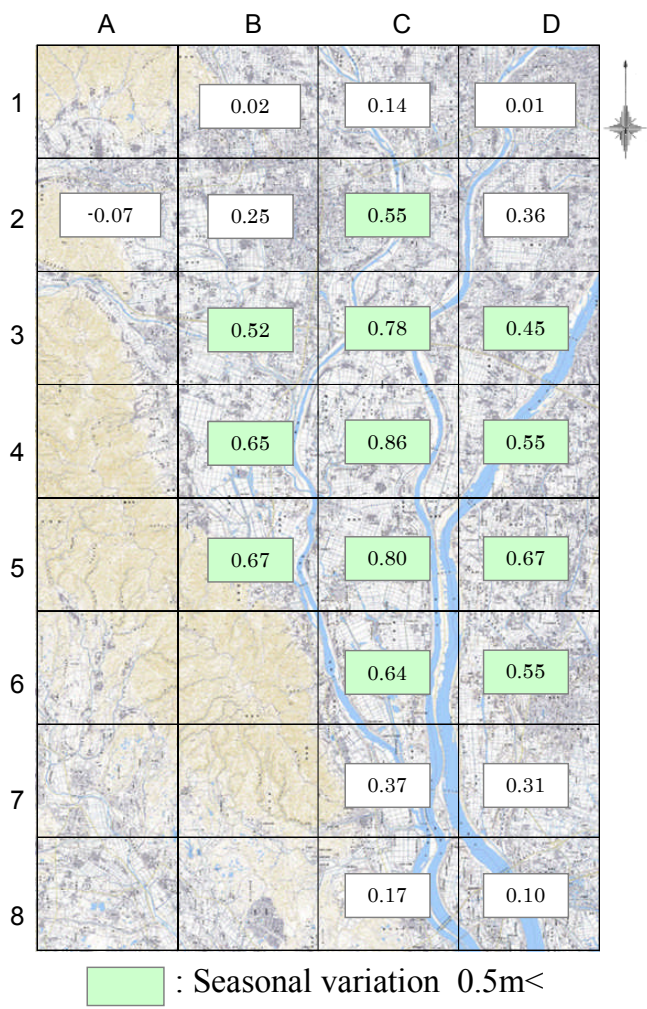

Figure 9. Seasonal variation of average value of groundwater level (1989-2006).

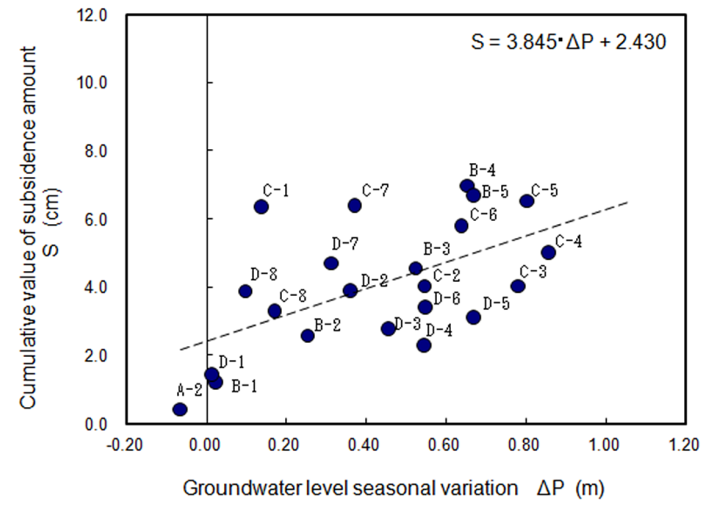

Figure 10. Cumulative value of land subsidence and seasonal variation groundwater level.

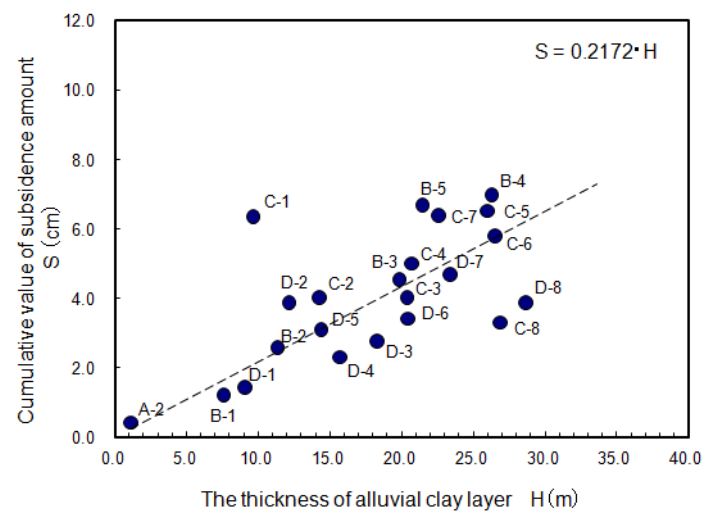

Figure 11. Cumulative value of land subsidence and thickness of the alluvial clay layer.

\subsection{Multiple regression analysis results}

The relationship between the amount of seasonal variation of groundwater level $(\Delta P)$ and the cumulative land subsidence $(S)$ is shown in Fig. 10. Calculated values vary widely and the correlation coefficient is low, $r=0.566$. One of the tendencies is that cumulative land subsidence is proportional to the increase of the amount of seasonal variation of groundwater level.

The relationship between the thickness of the alluvial clay layer $(H)$ and the cumulative land subsidence $(S)$ is shown in Fig. 11. The correlation coefficient is $r=0.650$. Cumulative land subsidence is largely proportional to the increase of the thickness of the alluvial clay layer.

Multiple regression analysis provides the influence of $(H)$ and $(\Delta P)$. The relationship between the measured and the calculated values of the cumulative land subsidence is shown in Fig. 12. The multiple correlation coefficient improves to $R=0.704$. 


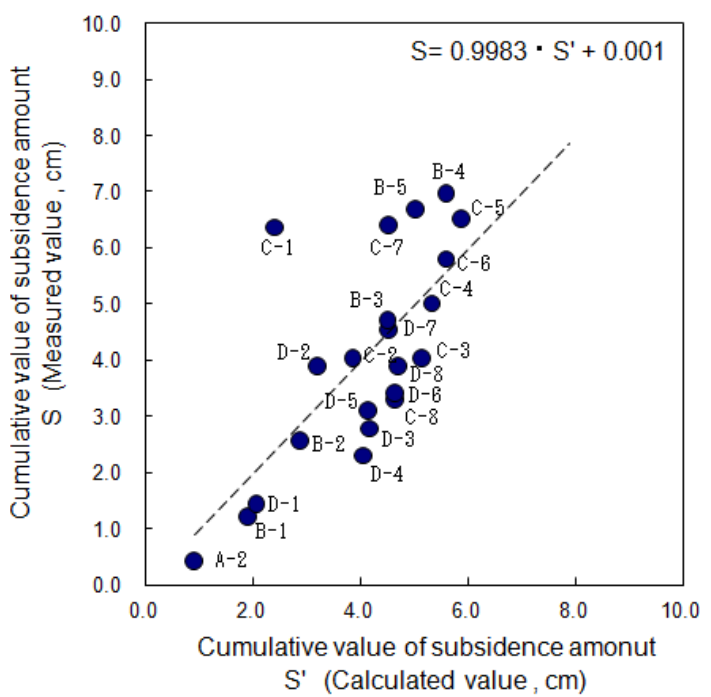

Figure 12. Comparison of Measured value and Calculated value of land subsidence.

\section{Discussions and conclusions}

Land subsidence occurs every year during the summer in the region where the thickness of soft alluvial clays deposits are greatest. The results of the multiple regression analysis suggests that the seasonal variation of the piezometric head is a suitable measure for describing the inducing factor of land subsidence, which is less than one centimeter per year in this area.

Consolidation curves under cyclical loading are below the normal consolidation line (NCL). It will takes a significant amount of time to reach the final land subsidence, which is greater than the NCL of the same level of an effective mean stress. Piezometric heads decline each year during the summer, which coincides with the cyclical loading curves in consolidation theory for alluvial clay layers.

This represents the main cause of continuous land subsidence over the long term at this site.

\section{References}

Gifu Prefecture: Report of Measures summary promote research for land subsidence revention, etc., 70-80, 2008.

Yasuhara, K. and Anderson, K. H.: Recompression of normally consolidated clay after cyclic loading, Soils and Foundations, 31, 83-94, 1991.

Land subsidence research meeting of tokai three Prefecture: Land subsidence and groundwater in Nobi Plain, 59-76, 1985. 